\title{
The Investigation of Arbuscular Mycorrhizal Fungal Effect on Growth and Nutrients in Trifolium pratense in The Multi Metals Contaminated Soil
}

\author{
Abed Vahedi ${ }^{1}$ \\ ${ }^{1}$ Department of Agronomy and Plant Breeding, Faculty of Agricultural and Natural Resources, Qaemshahr Branch, \\ Islamic Azad University, Qaemshahr, Iran \\ Correspondence: Abed Vahedi, Department of Agronomy and Plant Breeding, Faculty of Agricultural and Natural \\ Resources, Qaemshahr Branch, Islamic Azad University, Qaemshahr, Iran. E-mail: abedvahedy@gmail.com
}

Received: May 13, 2011 Accepted: June 15, 2011 Online Published: December 24, 2012

doi:10.5539/ijb.v5n1p71 URL: http://dx.doi.org/10.5539/ijb.v5n1p71

\begin{abstract}
Two pot culture experiments were carried out to study the effects of arbuscular mycorrhizal inoculation on the growth and nutrients uptake of Trifolium pratense. In first pot experiment, efficiency of four mycorrhizal strains: Glomus mosseae; Glomus etanicatum; Glomus intraradices and mixed strains (combination of Glomus mosseae, Gigaspora hartiga and Glomus fasciculatum), on the uptake of nutrients was investigated. Results showed that Glomus mosseae had the highest efficiency of uptake, translocation and distribution of $\mathrm{P}, \mathrm{N}$ and dry matter in alfalfa in comparison with the other strains. It can confirm existence of differences in ability of mycorrhizal strains in uptake and transport $\mathrm{P}$ into the shoot. A second experiment with heavy metal contaminated soil $(\mathrm{Cd}, \mathrm{Co}, \mathrm{Pb}$ and combinations) and inoculation to Glomus mosseae was executed. In this trial, uptake of nutrients depends on kind and mixture of metals was varied.
\end{abstract}

Keywords: Glomus mosseae, lead, cadmium, cobalt, Trifolium Pratense

\section{Introduction}

Large areas of soil are being contaminated by heavy metals, such as $\mathrm{Cu}, \mathrm{Zn}, \mathrm{Co}, \mathrm{Cr}, \mathrm{Ni}, \mathrm{Pb}$ and $\mathrm{Cd}$. Excessive heavy metals in the environment are known to be toxic to most organisms and their effects on organisms are being increasingly studied. Heavy metal effects on plants growth and causes structural damage and nutrients uptake (McGrath et al., 2001). Arbuscular mycorrhizae (AM) represent an almost ubiquitous relationship between soil microflora and plants. The fungal symbiont increases its host's uptake of nutrients and can improve its growth and resistance to environmental stresses (Smith \& Read, 2008).

Populations of AM are the key factor in soil development and successful plant establishment. Their presence may reduce stress caused by lack of nutrients or organic matter (Sylvia \& Williams, 1992).

Most land plants are symbiotic with arbuscular mycorrhizal fungi, which take up mineral nutrients from the soil and exchange them with plants for photosynthetically fixed carbon. Growth stimulation, better mineral nutrition and lower heavy metal uptake are among the benefits of mycorrhizal plants growing in soils with excessive levels of metals (Weissenhorn et al., 1995; Loth \& Höfner, 1995).

Heavy metals not only inhibit root growth but also can hamper many physiological processes and, in particular, the uptake of nutrients and it has been suggested that the nutrient status of the root may be a factor of vital importance for plant tolerance to changes in the environment (Gussarsson et al., 1994).

Heavy metals may decrease available contents of soils mineral nutrients (Derome \& Lindroos, 1998), by inhibiting the mineralization processes, and the litter decomposition rate in ecosystems under metal pollution stress is generally found to be reduced (Derome \& Lindroos, 1998; Ruhling et al., 1994).

Deficiency of nitrogen could have deleterious effects on the formation of heavy metal-complexing compounds and therefore on the tolerance to metals (Blaudez et al., 2000).

At different $\mathrm{Zn}$ levels, mycorrhizal colonization increases zinc absorption and accumulation in the roots. This may help to explain the alleviation of zinc toxicity at high concentrations (Chen et al., 2003). 
In legume plants the importance of AMF symbiosis has been attributed to high P requirements on the nodulation and $\mathrm{N}_{2}$ fixation process which requires enhanced P uptake (Barea \& Ázcón-Aguilar, 1983). Improved P nutrition has been indicated to increase in infertile and P fixing soils of the tropics (Smith \& Read, 2008).

The study described in this paper focused on the effect of the AM fungus Glomus mosseae on growth and nutrients uptake in a multi-metal-contaminated soil.

\section{Materials and Methods}

\subsection{Experiment 1}

The first experiment was set up for evaluation of efficiency of Mycorrhizae-Alfalfa symbiosis with five treatments in a Completely Randomized Design (CRD) [Glomus mosseae, G. etanicatum, G. intraradices, mixed strains (equal combination of G. mosseae, Gigaspora hartiga, G. fasciculatum) and un-inoculated (control)] with four replicates. Before the main experiments, strains were produced with the pot culture method. Inoculums were consisting of mixture of soil, root segments, mycelium and spores.

A sample of soil with clay $35 \%$, silt $40 \%$, sand $25 \%$, pH 7.91 and organic mater $1.48 \%$ was used. The soil was air-dried and then passed through $2 \mathrm{~mm}$ sieve, and large stones and plant root debris were removed and then, were filled in pots (10 kg soil for each pot). Mycorrhizae were applied as $50 \mathrm{~g}$ of inoculums mixed with $5 \mathrm{~cm}$ of upper surface of pot soil. Trifolium pratense L. seeds were treated with Sinorhizobium meliloti (prepared in the Soil and Water Research Institute, Tehran, Iran) before planting. After germination, plants were thinned to maintain a plant density of 5 plants per pot and watered with tap water as required.

In the early stage of flowering (135 days after planting), plants were harvested and were separated into stems and leaves. Samples dried in oven at $70^{\circ} \mathrm{C}$ for 48 hours, and then weighed, and ground.

Nutrients (P, Zn, Fe and K) and heavy metals concentration of samples was measured by Inductively Coupled Plasma Optical Emission Spectrometer (ICP-OES) (Variant-Liberty 150AX Turbo). Plant material was analysed for $\mathrm{N}$ by Kjeldahl digestion.

\subsection{Experiment 2}

The second experiment was set up in a $2 \times 8$ factorial completely randomised design, with four replicates. The first factor was inoculation (I) with $G$. mosseae or un-inoculation (I0). The second factor was included seven levels of contaminants: $(\mathrm{Co}, \mathrm{Cd}, \mathrm{Pb}, \mathrm{CoCd}, \mathrm{CdPb}, \mathrm{PbCo}$ and $\mathrm{PbCoCd})$ plus an uncontaminated control treatment $(\mathrm{C})$. Same two previous experiments, a sample of soil (clay $35 \%$, silt $40 \%$ and sand $25 \%$ ) were used. Total Co content $=51.91$ $\mathrm{mg} \mathrm{kg}{ }^{-1}$ dried soil, total $\mathrm{Cd}$ content $=8.5 \mathrm{mg} \mathrm{kg}^{-1}$ dried soil and total $\mathrm{Pb}$ content $=436 \mathrm{mg} \mathrm{kg}^{-1}$ dried soil. The heavy metal salts used included $\mathrm{CoSO}_{4}, \mathrm{CdCl}_{2}$ and $\mathrm{Pb}\left(\mathrm{NO}_{3}\right)_{2}$.

The soil was contaminated before planting by adding the calculated amounts of heavy metal salts in distilled water and mixed throughout the soil profile. They were allowed to stabilise for 15 days. Then, $50 \mathrm{~g} \mathrm{G}$. mosseae inoculum was mixed with $5 \mathrm{~cm}$ of upper surface of soil and Alfalfa seeds planted as before. After germination, plants were thinned to maintain a plant density of 5 plants per pot. During the trial, tap water was used as source of irrigation.

Plants were cut from soil surface in early flowering stage. Roots were extracted from pot. Aboveground materials separated into the stems and leaves were washed by distilled water. Plant material was dried at $70^{\circ} \mathrm{C}$ for 48 hours.

Heavy metals and nutrients ( $\mathrm{P}, \mathrm{K}, \mathrm{Cu}, \mathrm{Zn}$ and $\mathrm{Fe}$ ) quantified by Inductively Coupled Plasma Optical Emission Spectrometer (ICP-OES) (Variant-Liberty 150AX Turbo). N concentration determined by Kjeldahl digestion.

\section{Results}

\subsection{Experiment 1 Results}

\subsubsection{Leaf and Stem Biomass}

Leaf biomass varied greatly among the mycorrhizal strains (Table 1). The G. mosseae had significantly more leaf biomass (Table 1) $(P<0.05)$. Significant differences were detected for mycorrhizal treatments based on stem weight. The G. mosseae substantially increased stem biomass accumulation of plants grown (Table 1) $(P<0.05)$.

\subsubsection{Shoot $\mathrm{P}$}

Aboveground $\mathrm{P}$ was influenced by mycorrhizal strains and G. mosseae significantly increased $\mathrm{P}$ than other strains (Table 1) $(P<0.05)$.

\subsubsection{Shoot $\mathrm{N}$}

Shoot nitrogen concentration was significantly more for plants inoculated with mixed strains. In the case of plants inoculated with G. mosseae, shoot N concentration was significantly lower than the control (Table 1) $(P<0.05)$. 


\subsubsection{Shoot K}

Different strains had significantly differences. The highest tissue K concentration was in G. mosseae (1787.65 $\mathrm{mg}$ $\mathrm{kg}^{-1}$ ), followed by control $\left(1701.66 \mathrm{mg} \mathrm{kg}^{-1}\right)$ and mixed strains $\left(1648.06 \mathrm{mg} \mathrm{kg}^{-1}\right)$ (Table 1) $(P<0.05)$.

\subsubsection{Shoot Zn}

The mycorrhizal trains had significantly varied ability in $\mathrm{Zn}$ uptake Shoot $\mathrm{Zn}$ content was higher in G. mosseae than others (Table 1) $(P<0.05)$.

\subsubsection{Shoot $\mathrm{Fe}$}

Mycorrhization hadn't increased Fe content of shoot significantly. The control plants had higher Fe concentration than inoculated plants (Table 1) $(P<0.05)$. G. etunicatum had the highest Fe content among the strains (Table 1) $(P<0.05)$.

Table 1. Mean comparison of effect of different mycorrhizal strains on biomass and nutrients uptake of alfalfa (exp. 1)

\begin{tabular}{llllllll}
\hline Treatments & $\begin{array}{l}\text { Leaf } \\
\text { biomass }(\mathrm{g})\end{array}$ & $\begin{array}{l}\text { Stem } \\
\text { biomass }(\mathrm{g})\end{array}$ & $\begin{array}{l}\text { Shoot P } \\
\left(\mathrm{mg} \mathrm{kg}^{-1}\right)\end{array}$ & $\begin{array}{c}\text { Shoot N } \\
(\%)\end{array}$ & $\begin{array}{l}\mathrm{K} \\
\left(\mathrm{mg} \mathrm{kg}^{-1}\right)\end{array}$ & $\begin{array}{l}\mathrm{Zn} \\
\left(\mathrm{mg} \mathrm{kg}^{-1}\right)\end{array}$ & $\begin{array}{l}\mathrm{Fe} \\
\left(\mathrm{mg} \mathrm{kg}^{-1}\right)\end{array}$ \\
\hline Control & $15.86^{\mathrm{b}}$ & $7.26^{\mathrm{b}}$ & $1243.04^{\mathrm{c}}$ & $3.05^{\mathrm{b}}$ & $1701.66^{\mathrm{b}}$ & $23.60^{\mathrm{e}}$ & $712.72^{\mathrm{a}}$ \\
G. etunicatum & $16.14^{\mathrm{ab}}$ & $8.57^{\mathrm{b}}$ & $1287.52^{\mathrm{c}}$ & $2.92^{\mathrm{b}}$ & $1530.91^{\mathrm{d}}$ & $37.70^{\mathrm{b}}$ & $507.10^{\mathrm{b}}$ \\
G. intraradices & $15.75^{\mathrm{b}}$ & $8.73^{\mathrm{b}}$ & $1287.52^{\mathrm{b}}$ & $2.99^{\mathrm{b}}$ & $1515.35^{\mathrm{d}}$ & $29.52^{\mathrm{d}}$ & $284.98^{\mathrm{e}}$ \\
mixed strains & $16.21^{\mathrm{ab}}$ & $8.33^{\mathrm{b}}$ & $1284.01^{\mathrm{b}}$ & $3.21^{\mathrm{a}}$ & $1648.06^{\mathrm{c}}$ & $33.09^{\mathrm{c}}$ & $369.79^{\mathrm{c}}$ \\
G. mosseae & $17.6^{\mathrm{a}}$ & $11.09^{\mathrm{a}}$ & $1451.95^{\mathrm{a}}$ & $3.02^{\mathrm{b}}$ & $1787.65^{\mathrm{a}}$ & $45.88^{\mathrm{a}}$ & $316.98^{\mathrm{d}}$
\end{tabular}

Mean values within the same column, followed by different letters are significantly different using Duncan's multiple range test $(P<0.05)$.

\subsection{Experiment 2 Results}

\subsubsection{Shoot $\mathrm{N}$}

In without heavy metal pots, IC treatment had significantly shoot $\mathrm{N}$ content more than I0C. Shoot $\mathrm{N}$ content was higher in $\mathrm{ICo}, \mathrm{ICd}$ and $\mathrm{IPb}$ than un-inoculated plants $(\mathrm{I} 0 \mathrm{Co}, \mathrm{I} 0 \mathrm{Cd}$ and $\mathrm{I} 0 \mathrm{~Pb})$ by G. mosseae. But, in the contaminated pots to $\mathrm{PbCo}$ and $\mathrm{PbCoCd}$, un-inoculated plants had more $\mathrm{N}$ concentration than inoculated ones (Figure 1a) $(P<0.05)$.

\subsubsection{Plant $\mathrm{P}$}

Comparison of controls indicated IC produced the most amount of whole plant phosphorous. Inoculation of plants with G. mosseae fungi significantly increased P content of whole alfalfa plants at contaminated pots to Co, $\mathrm{Pb}$ and $\mathrm{PbCd}$. In the rest of treatments, un-inoculated plants had more phosphorous than inoculated ones (Figure 1b) $(P<0.05)$.

\subsubsection{Shoot $\mathrm{K}$}

Results revealed that in the dual inoculation of $\mathrm{C}, \mathrm{Co}, \mathrm{Cd}, \mathrm{Pb}, \mathrm{CoCd}$ and $\mathrm{PbCd}$ and G. mosseae fungi, Shoot $\mathrm{K}$ was higher. But, in the $\mathrm{PbCo}$ and $\mathrm{PbCoCd}$ polluted and un-inoculated pots shoot concentration of $\mathrm{K}$ was more than inoculated plant with G. mosseae (Figure 1c) $(P<0.05)$. 

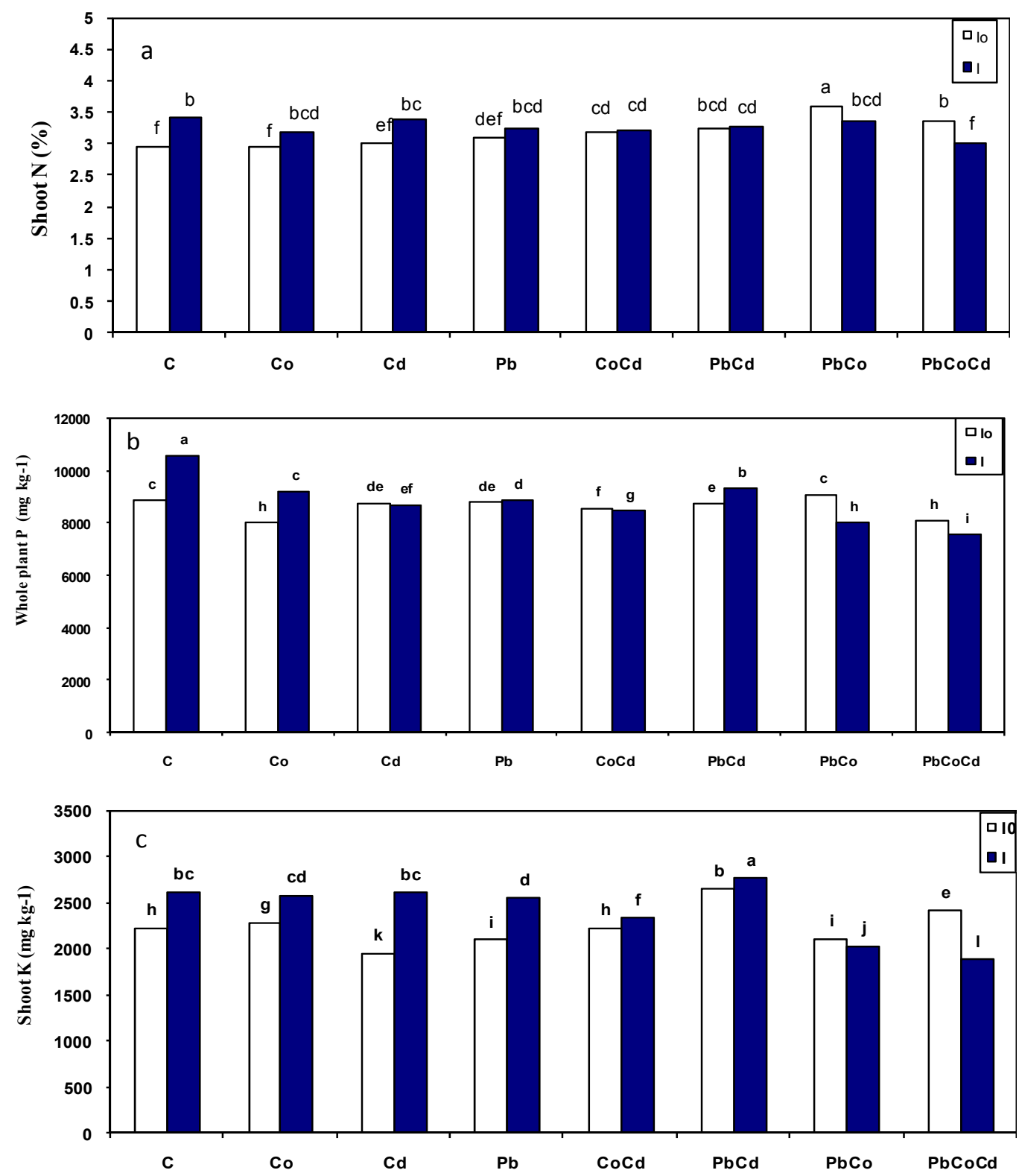

Figure 1. Nutrients contents of plant tissues as affected by heavy metals concentrations for control and mycorrhizal treatments

Mean values within the same column, followed by different letters are significantly different using Duncan's multiple range test $(P<0.05)$. C: Control, I0: Un-inoculated plants, I: Inoculated plants with G. mosseae.

\subsubsection{Shoot $\mathrm{Cu}$}

The results obtained proved that in the uncontaminated pots, un-inoculated plants more $\mathrm{Cu}$ concentration of shoot. In the heavy metals contaminated soil different behaviour respect to type and combinations on contaminants was observed. In the polluted pots to $\mathrm{Cd}, \mathrm{CoCd}, \mathrm{PbCd}$ and $\mathrm{PbCoCd}$ un-inoculated plants produced significantly more amounts of shoot $\mathrm{Cu}$ (Figure $2 \mathrm{a})(P<0.05)$.

\subsubsection{Shoot Fe}

In the control treatment, there was $\mathrm{IC}<\mathrm{I} 0 \mathrm{C}$. In the polluted pots to $\mathrm{Co}, \mathrm{Cd}, \mathrm{Pb}, \mathrm{CoCd}, \mathrm{PbCd}$ and $\mathrm{PbCo}$, un-inoculated plants with G. mosseae showed a significant $(P<0.05)$ increase in Fe content of shoot. At $\mathrm{PbCoCd}$ contaminated pots, G. mosseae significantly $(P<0.05)$ enhanced, Fe concentration of shoot compared to controls (Figure 2b). 


\subsubsection{Shoot $\mathrm{Zn}$}

In the control and $\mathrm{Co}, \mathrm{Cd}$ and $\mathrm{PbCo}$ polluted pots non-inoculated plants had significantly more $\mathrm{Zn}$ concentration than inoculated plants. But, in $\mathrm{Pb}, \mathrm{CoCd}, \mathrm{PbCd}$ and $\mathrm{PbCoCd}$ inoculation with $G$. mosseae increased significantly Zn concentration of shoot (Figure 2c) $(P<0.05)$.
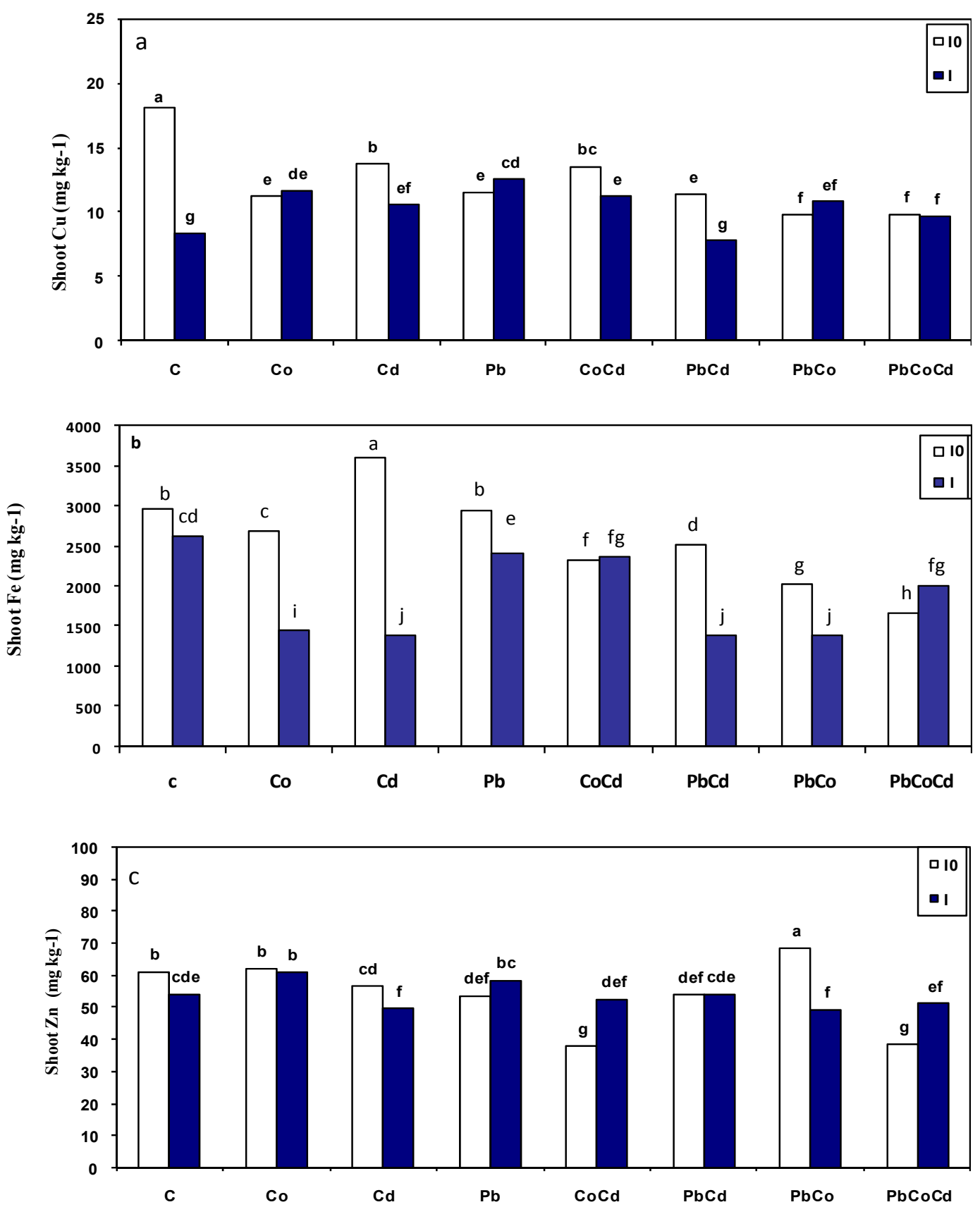

Figure 2. Nutrients contents of plant tissues as affected by heavy metals concentrations for control and mycorrhizal treatments

Mean values within the same column, followed by different letters are significantly different using Duncan's multiple range test $(P<0.05)$. C: Control, I0: Un-inoculated plants, I: Inoculated plants with $G$. mosseae. 


\section{Discussion}

In the experiment 1, all strains of mycorrhizae produced more content of $\mathrm{P}, \mathrm{K}, \mathrm{N}, \mathrm{Zn}$, leaf, stem and shoot biomass than control plants (Table 1). Reviewed literatures show legumes have a relatively high P requirement for nodule development and nitrogen fixation, therefore normal levels of nodulation may depend on the presence of mycorrhizal Fungi (Powell, 1976; Barea et al., 1988). The extra P in mycorrhizal roots could be due either to better soil exploration by the extramatrical mycelium, or to the ability of the fungus to utilize or mobilize sources of soil $\mathrm{P}$ not available to plant roots. The primary mechanism by which mycorrhizal fungi improve $\mathrm{P}$ uptake is through more extensive soil exploration rather than a unique capacity to mobilize sources of $\mathrm{P}$ not available to plants (Sanders \& Tinker, 1971; Hayman \& Mosse, 1972).

Despite its importance as a nutrient, very little is known about AMF uptake nitrogen and translocation it to the host plants. Mycorrhizal plants had more amounts of leaf area, leaf, shoot and root dry mater and N, K, P, Cu, Fe and Zn concentration than un-inoculated plants (Davies et al., 2005). Tawaraya et al. (1999) reported that welsh onion cultivars were highly colonized with G. fasciculatum. Shoot P uptake and shoot dry weight were different among cultivars and were increased by mycorrhizal colonization. Other investigation indicated mycorrhizal symbiosis enhanced P (Harley \& Smith, 1983), N, K, Mg (Liu et al., 2002) and Zn (Jamal et al., 2002) uptake. Gilmore (1971) showed that arbuscular mycorrhizal fungus could increase host $\mathrm{Zn}$ content, and Ross and Harper (1970) demonstrated the same result for $\mathrm{Cu}$. Mycorrhizal strains hadn't increased Fe concentration of shoot significantly. There are contrasting reports about effect of mycorrhizae on Fe content of plant. Some reports showed AM symbiosis decreased, increased or had no effect on shoot concentration of Fe (Auge, 2001).

In the experiment 2 , interactions between heavy metals and nutrients uptake have been mainly varied in inoculated and un-inoculated plants. A vast amount of literature is available on the effects of mycorrhizae on plants under heavy metals stress. But, the effects of two or three heavy metals and AM were not investigated on plant growth and nutrients take up and translocation of them into shoot. Only a few studies have demonstrated the effect of heavy metals on nutrients uptake by plants, because the interactions are complicated by the presence of mycorrhizal symbionts.

The effects of AMF on the heavy metal uptake of mycorrhizal plants are metal specific and depend on metal concentration and availability, plant species, AMF species, soil properties, or some other unidentified factors (Wang et al., 2007).

\section{Conclusion}

The presented results show that in the contaminated soil reaction of G. mosseae was different. For example: in the mono metal contaminated pots mycorrhizal plants had more $\mathrm{N}$ of shoot but in the $\mathrm{PbCd}, \mathrm{PbCo}$ and $\mathrm{PbCoCd}$ contaminated pots un-inoculated plants had higher N than inoculated ones. Such results also obtained for other nutrients. The amount of nutrients uptake was affected on type and combination of heavy metals.

\section{References}

Asp, H., Gussarsson, M., Adalsteinsson, S., \& Jensën, P. (1994). Control of potassium influx in roots of birch (Betula pendula) seedlings exposed to cadmium. Journal of Experimental Botany, 45, 1823-1827. http://dx.doi.org/10.1093/jxb/45.12.1823

Augé, R. M. (2001). Water relations, drought and vesicular-arbuscular mycorrhizal symbiosis. Mycorrhiza, 11, 3-42. http://dx.doi.org/10.1007/s005720100097

Barea, J. M., Azcon-Aguilar, C., \& Azcon, R. (1988). The role of mycorrhiza in improving the establishment and function of the Rhizobium- legume system under field conditions. In: D. P. Beck \& Materon, L. A. (Eds), Nitrogen fixation by legumes in Mediterranean agriculture. Nijhof, Dordrecht. http://dx.doi.org/10.1007/978-94-009-1387-5_17

Barea, J. M., \& Azcon-Aguilar, C. (1983). Mycorrhizas and their significance in nodulating nitrogen-fixing plants. Advance in Agronomy, 36, 1-54. http://dx.doi.org/10.1016/S0065-2113(08)60351-X

Blaudez, D., Botton, B., \& Chalot, M. (2000). Effects of heavy metals on nitrogen uptake by Paxillus involutus and $\begin{array}{lllll}\text { mycorrhizal birch seedlings. FEMS Microbial Ecology, } & \text { 33, }\end{array}$ http://dx.doi.org/10.1111/j.1574-6941.2000.tb00727.x

Caravaca, F., Alguacil, M. M., Azcon, R., Diaz, G., \& Roldan, A. (2004). Comparing the effectiveness of mycorrhizal inoculation and amendment with sugar beet, rock phosphate and Aspergillus niger to enhance field performance of the leguminous shrub Dorycnium pentaphyllum L. Applied Soil Ecology, 25, 169-180. http://dx.doi.org/10.1016/j.apsoil.2003.08.002 
Caravaca, F., Alguacil, M. M., Figueroa, D., Barea, J. M., \& Roldan, A. (2003). Re-establishment of Retama sphaerocarpa as a target species for reclamation of soil physical and biological properties in a semi-arid

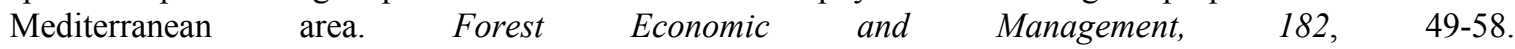
http://dx.doi.org/10.1016/S0378-1127(03)00067-7

Chen, B. D., Li, X. L., Tao, H. Q., Christie, P., \& Wong, M. H. (2003). The role of arbuscular mycorrhiza in zinc uptake by red clover growing in calcareous soil spiked with various quantities of zinc. Chemosphere, 50, 839-846. http://dx.doi.org/10.1016/S0045-6535(02)00228-X

Davies, F. T., Calderon, C. M., \& Hauman, Z. (2005). Influence of arbuscular mycorrhiza indigenous to peru and flavonoid on growth, yield and leaf elemental concentration of yungay potatoes. Horticulture Science, 40, 381-385.

Derome, J., \& Lindroos, A. J. (1998). Effects of heavy metal contamination on macronutrient availability and acidification parameters in forest soil in the vicinity of the Harjavalta $\mathrm{Cu}-\mathrm{Ni}$ smelter, SW Finland. Environmental Pollution, 99, 225-232. http://dx.doi.org/10.1016/S0269-7491(97)00185-1

Gilmore, A. E. (1971). The influence of endotrophic mycorrhizae on the growth of peach seedlings. Journal of American Society of Horticultural Science, 96, 35-47.

Harley, J. L., \& Smith, S. E. (1983). Mycorrhizal symbiosis. Academic Press, London, UK.

Hayman, D. S., \& Mosse, B. (1972). Plant growth responses to vesicular arbuscular mycorrhiza. III. Increased $\begin{array}{llllll}\text { uptake of labile } \mathrm{P} \text { from soil. New Phytology, } & \text { 71, }\end{array}$ http://dx.doi.org/10.1111/j.1469-8137.1972.tb04808.x

Jamal, A., Ayub, N., Usman, M., \& Khan, A. G. (2002). Arbuscular mycorrhizal fungi enhance Zinc and nickel uptake from contaminated soil by soybean and lentil. International Journal of Phytoremediation, 4, 203-221. http://dx.doi.org/10.1080/15226510208500083

Kothari, S. K., Marschner, H., \& Romheld, V. (1990). Direct and indirect effects of VA mycorrhizae and rhizosphere microorganisms on mineral nutrient acquisition by maize (Zea mays L.) in a calcareous soil. New Phytololoy, 116, 637-645. http://dx.doi.org/10.1111/j.1469-8137.1990.tb00549.x

Liu, A., Hamel, C., Eimi, A., Costa, C., Ma, B., \& Smith, D. L. (2002). Concentrations of K, Ca and Mg in maize colonized by arbuscular mycorrhizal fungi under field conditions. Canadian Journal of Soil Science, 82, 271-278. http://dx.doi.org/10.4141/S01-022

Loth, F. G., \& Höfner, W. (1995). Einfluss der VA-mykorrhiza auf die Schwermetallaufnahme von Hafer (Avena sativa L.) in Abhängigheit vom Kontaminationsgrad der Böden. ZPflanzenernaehr Bodenk, 158, 339-345. http://dx.doi.org/10.1002/jpln.19951580405

MarVazquez, M., Cesar, S., Azcon, R., \& Barea, J. M. (2000). Interactions between arbuscular mycorrhizal fungi and other microbial inoculants (Azospirillum, Pseudomonas, Trichoderma) and their effects on microbial population and enzyme activities in the rhizosphere of maize plants. Applied Soil Ecology, 15, 261-272. http://dx.doi.org/10.1016/S0929-1393(00)00075-5

McGrath, S. P., Zhao, F. J., \& Lombi, E. (2001). Plant and rhizosphere processes involved in phytoremediation of metal-contaminated soils. Plant and Soil, 232, 207-214. http://dx.doi.org/10.1023/A:1010358708525

Moreno, J. L., Garcia, C., \& Hernandez, T. (2003). Toxic effect of cadmium and nickel on soil enzymes and the influence of adding sewage sludge. European Journal of Soil Science, 54, 377-386. http://dx.doi.org/10.1046/j.1365-2389.2003.00533.x

Powell, C. L. (1976). Mycorrhizal fungi stimulate clover growth in New Zealand hill country soils. Nature, 264, 436-438. http://dx.doi.org/10.1038/264436a0

Ross, J. P., \& Harper, J. A. (1970). Effect of Endogone mycorrhiza on soybean yields. Phytopathology, 60, 1552-1556. http://dx.doi.org/10.1094/Phyto-60-1552

Ruhling, A., Baath, E., Nordgren, A., \& Soderstrom, B. (1984). Fungi in metal-contaminated soil near the Gusum Brass Mill, Sweden. Ambiology, 13, 34-36.

Sanders, F. E., \& Tinker, P. B. (1971). Mechanism of absorption of phosphate from soil by Endogone mycorrhizas. Nature, 233, 278-279. http://dx.doi.org/10.1038/233278c0

Smith, S. E., \& Read, D. J. (2008). Mycorrhizal Symbiosis. Academic Press, London, UK. 
Sylvia, D. M., \& Williams, S. E. (1992). Vesicular-arbuscular mycorrhizae and environmental stress. In G. J. Bethenfalvay \& R. G. Linderman (Eds.), Mycorrhizae in Sustainable Agriculture (pp. 101-124). ASA Special Publication No. 54, ASA, CSSA, SSSA, Madison, WI.

Tawaraya, K., Imai, T., \& Wagatsuma, T. (1999). Importance of root length in mycorrhizal colonization of Welsh Onion. Journal of Plant Nutrition, 22, 589-596. http://dx.doi.org/10.1080/01904169909365654

Vivas, A., Barea, J. M., \& Azcon, R. (2005). Interactive effect of Brevibacillus brevis and Glomus mosseae, both isolated from $\mathrm{Cd}$ contaminated soil, on plant growth, physiological mycorrhizal fungal characteristics and soil enzymatic activities in Cd polluted soil. Environmental Pollution, 134, 257-266. http://dx.doi.org/10.1016/j.envpol.2004.07.029

Wang, F. Y., Lin, X. G., \& Yin, R. (2007). Effect of arbuscular mycorrhizal fungal inoculation on heavy metal accumulation of maize grown in a naturally contaminated soil. International Journal of Phytoremediation, 9, 345-353. http://dx.doi.org/10.1080/15226510701476214

Weissenhorn, I., Mench, M., \& Leyval, C. (1995). Bioavailability of heavy metals and arbuscular mycorrhiza in sewage sludge-amended sandy soil. Soil Biology and Biochemistry, 27, 287-296. http://dx.doi.org/10.1016/0038-0717(94)00179-5 